\title{
ACCESS AND USE OF ICT IN SCHOOL MANAGEMENT IN MINDANAO STATE UNIVERSITY MAIN CAMPUS
}

\author{
Jehanie May A. Macasawang \\ Ranao Council - Al Khwarizmi International College Foundation, Inc. \\ Email: rcakicmain@gmail.com
}

\begin{abstract}
In the digital era, the ability of schools to access and provide ICT resources is very important. This study examines the level of accessibility and use of ICT resources in school management in Mindanao State University main campus (MSU MC). It aims to give a picture of the current profile of the ICT facilities in the university particularly those employed for school management through describing the accessibility of those ICT facilities by taking into account their availability and convenience of access and its use by pertaining to the ICT user-ability of the human resource of the university

This study was incited due to the visible difficulties met by the students as well as the teacher and staff in the school management activities in MSU MC despite the application of ICT in it. The data for this study were collected through a semistructured survey, interviews, and document reviews of related literatures. Correlation of the variables was tested using the chi-square test. And the comparative analysis of the opinions of the groups of respondents was done through a t-test.

The results of this study find that over-all, the current ICT facility of the university is claimed as fairly effective in school management that only Plagiarism is seen as the most prevalent negative consequence on its implementation. In addition, the correlation analysis in this study discloses that ICT accessibility and user-ability have no direct relationship with effective school management. And although the comparative analysis showed that there is a significant difference of opinions between the groups of respondents, its statistical value proved only that the variance of the opinions of the groups of respondents is only little. These results evidently reflect that the ICT facility in MSU MC is not so much defective. However, the research results also reveal that the problems in the availability and convenience of ICT tools in MSU MC as well as in the user-ability of the human resource in ICT are pretty much important aspects of an excellent ICT facility like strong internet bandwidth, need of maintenance and update on latest ICT trends, motivation to use ICT tools, etc. Thus, this study recommends that the ICT resources in MSU MC for school management should be further developed as seen appropriate
\end{abstract}

Keywords: Access; Education; ICT; Information Technology; Marawi

\section{INTRODUCTION}

The advent of the Information and

Communication Technology (ICT) has

come a long way since the year 1833

when the British Mathematician and

Scientist, Charles Babbage invented the

Analytical Engine Machine, the first general-purpose digital computer
(Microsoft Encarta 2009 [DVD], 2009). Now, we live in a generation coined as the computer age where the influence of ICT has become excessively prevalent in the society and in our daily lives. In the present, every industry in the worldmedia, trade, transportation, and among others-ICT is applied. Thus, it is no wonder 
anymore that even in the education system, ICT has been embedded too. In effort to engage ICT to improve student learning and with the emergence of knowledge economy which conveyed great emphasis on education, the increase of interest, attention and investment are being laid into the use of ICT in education all over the world (Ahmad, 2010).

School management remains a vital factor for any academic achievement in a university. Thus, refining an educational institution's capacity in running its organization has become an important venture. With the exponential growth of the usage of ICT and its pervasive impacts both on society and on our daily lives, ICT has also been drive into school management procedures. Computerized systems are employed to ensure transfer speed, transparency and organization of data.

Currently, the Mindanao State University (MSU) main campus has the Information Technology Centre (ITC) to answer to the rapid growth of information-based and knowledge-based technologies through the use of computers and highly advanced communication systems (MSUS, 2007). The ITC is composed of three (3) departments, namely: Information System Department (ISD), Internet Services Centre (ISC), and Support Services and Training Department (SSTD) (MSUS, 2007). The ISD does all computerization, data networking, and programming jobs of the university (MSUS, 2007). The ISC controls the use, access and network distribution of Internet Services in the campus. Then the SSTD serves as the maintenance arm of the ITC (MSUS, 2007).

However, even with all this effort, it remained not enough. MSU Main Campus (MSU MC) still faced the challenge of how to transform the entire institution into a technology-driven environment through $I C T$, both in learning and teaching process and school management. This is not entirely the fault of the administration of MSU System (MSUS). Since MSU MC is located in an almost far-flung area, it is hard for the university to hire and retain qualified ICT personnel. Due to this geographical problem too, acquiring sufficient bandwidth to support systems in the university is difficult which then results to problem in contracting outsourced services.

However, it can be asserted that the MSUS administration has indeed taken the development of ICT in the university in a piecemeal way as can be seen in the history of its implementation where the College of Information Technology (CIT) only started to become a fully collegiate unit of the university with the ITC and the Computer Studies Department (CSD) in the year 2005. This could be in view of the unrealized importance of the need to 
enhance and develop the ICT in the university particularly in the school management area by the MSUS administration. This particular attitude of the MSUS towards ICT probably resulted from the intended clients' or users' reluctance to use ICT tools and generally from the opposition of the stakeholders on ICT which perhaps ensued from low level of ICT skills. In view of this discrepancies, the need to examine the accessibility and user-ability of ICT resources mainly on the school management aspect of the university is a must.

ICT has been a term used by academic researchers since the 1980s (Melody, 1986). But its popularity came only in 1997 after it was applied by Dennis Stevenson in a report to the UK government (The Independent ICT in Schools Commission, 1997) and in the revised National Curriculum for England, Wales and Northern Ireland in 2000. It is often referred synonymously with Information Technology (IT). But the two are actually different in a way that the former (ICT) is a more specific term referring to the part of unified communications and incorporation of telecommunications, computers, as well as necessary enterprise software, middleware (software connecting client and database) (Microsoft Encarta 2009 [DVD], 2009), storage, and audio-visual systems, which enable users to access, store, transmit, and manipulate information (Foldoc, n.d.). As an industry, ICT continues to grow at an exponential rate, branching into a wide array of specialties such as software engineering, networking, telecommunications and Artificial Intelligence (Ntetha, 2010).

As a whole, by processing and transforming data into information, ICT have come to play a central role in the daily lives of the people. It has revolutionized work and leisure and changed the rules of doing business (Ntetha, 2010). ICTs are communication enablers-regionally, nationally, and internationally-and a prime mover of information sharing, knowledge and development (International Telecommunication Union, 2007). It has enhanced many aspects of the daily lives in a society. Patients in a hospital can now get their HIV/AIDS results within an hour, instead of days because of the technologies that have been implemented in hospitals. An individual can now withdraw money in seconds from a computerised Automated Teller Machine (ATM) without having to stand in queves waiting for assistance from the banker/teller. And with the smart phone technology, most services like the news, buy and sell can now be done literally at the palm of our hands.

In education, ICT, according to the SER (1998) of the Netherlands, can be characterized into four: as an object, as an 'assisting tool', as a medium for teaching and learning, and as a tool for organization and management in schools. ICT as an 
object refers to ICT as a course of study. Then, ICT as an assisting tool in education refers to how ICT resources aid in completing tasks such as while making assignments, etc. While, ICT as a medium for teaching and learning refers to ICT as a tool for teaching and learning itself, the medium through which teachers can teach and learners can learn. Lastly, ICT as a tool for organization and management in schools refers to how ICT helps in the managerial procedures of an institution particularly in educational institution.

On the other hand, according to the World Bank Group (WBG), ICT components typically assist Education in the following: (i) Supplying computers and connectivity and building school computer labs, (ii) Enabling instruction in computer programming and computer literacy, (iii) Developing and disseminating new curricula in electronic format, (iv) Distance Learning, and (v) Enabling better administration in the education sector, particularly through the development of Education Management Information Systems (EMIS).

Management Information System or MIS, the system that provides information that organizations require to manage themselves efficiently and effectively (OCC, 2010) is actually the concept applied to the use of ICT in organizations. In the education sector, it is called as an EMIS, shortened for Education Management Information System. On a more specific level such as in the area of school management, a more specific EMIS is used called the School Information System (SIS) which is also sometimes known as School Management System. A SIS is an application software that manages all of a school's data in a single, integrated applications (IGSCE ICT, 2014). The advantages of the usage of a SIS according to the (The ICT Lounge, 2014) are the following: (i) Provide up-to-date student information, (ii) Easy to search records, (iii) Easy to update records, (iv) Easier for the teachers and the school administration in general to produce and print student reports, and (v) Some systems works online which allows parents and students to see their progress from home.

In this research, since accessible refers to the lack of difficulty in obtaining, using, or experiencing a specific thing and the quality of physical ease in entering and reaching a certain object (Microsoft Encarta 2009 [DVD], 2009), access to ICT resources is defined as the availability or the condition of being available or obtainable of the ICT resources and the convenience of access or the straightforwardness of getting through to the ICT resources. Use of ICT resources in this research conversely refers to the level of knowledge and skills or the user-ability of ICT resources which is deemed as one of the five key pillars of successful integration of ICT in schools (National Council for Curriculum and Assessment, UK, 2004).

Generally, it is a widely accepted idea that the use and benefits of ICT has altered the ways of life of people all over the world. 
According to (Megan, n.d.), the use of ICT is consisted of the following: (i) Delivering Services, (ii) Sharing Innovation, (iii) Back Office Processes, (iv) Collaborative Working, and ( $v$ ) Reaching Users. On the other hand, according to (Sopchokchai, 2004), the benefits of ICT are the following: (i) Convenience, (ii) Customization, (iii) Improving transparency and build trust, (iv) More active citizen interaction and democratic participation in decisionmaking process, and (v) Improved public service.

While in education, a research conducted by the government of Norway identified five uses of ICT in Education (Network for ITResearch and Competence In Education, 2004) which are the following: (i) Better student performance, (ii) Greater motivation and responsibility for students' own learning, (iii) More professional teacher role, (iv) More effective school administration, and ( $v$ ) More individualized teaching. The benefits of ICT in education conversely is divided into three categories by the British Educational Communication and Technology Agency (BECTA)according to the benefits of the School Leaders, the Teachers and Non-Teaching staff, and of course, the Parents.

For School Leaders, the benefits of ICT in education are the following:

- Use of online conferencing can help reduce professional isolation and provide tested management solutions (Crawford, 2001).
- Contact lists, diaries and meeting arrangements can be kept up to date and fully synchronized across a management team or the whole school staff when handheld computers are used [ (Perry, 2003) \& (Telem, 2001)].

- Shared leadership models help cope with the expansion of ICT and manage workloads (Yee, 2000).

- Effectively using SISs can reduce time spent on administrative tasks, but compatibility of systems is a key factor [ (Bushweller, 2000) \& (North, Strain, \& Abbott, 2000)].

For Teachers and Non-Teaching Staff, the benefits of ICT in education are the following:

- All levels of staff can play a greater role in the school due to new and flexible management structures facilitated by ICT (Evans, 2002).

-Where school leaders are enthusiastic and visionary about $I C T$, it can yield significant workload reductions whilst securing undoubted advances, in addition to direct curriculum benefits (Price Water House Coopers (PWC), 2001).

And for the Parents, the benefits of ICT in education are the following:

- Greater access to more accurate attendance and attainment 
information (Price Water House Coopers (PWC), 2001)

- Easier communication with and access to head teacher and teachers through using ICT

While in school management, ICT's use and benefits can be summarized to the effective administration of the school through accurate and fast operation of school's tasks. It takes a vital role in supporting powerful, efficient management and administration in education sector (Unachukwu \& Nwankwo, 2012). It plays a major role in reducing operational inefficiency and improving decision-making in many areas of governance in schools and school administrative subsystems including personnel administration, student administration, resources administration, financial administration and general administration (Maki, 2008). It facilitates and supports sustainable development in schools (Ghavifekr, Afshari, Saedah, \& Sigir, 2013). In management of higher education, (Kumar, Rose, \& D'Silva, 2008) reveal that the integration of ICT helps to reduce the complexity and enhance the overall administration of this establishment. Enhancing the usage of ICT in functional areas especially for general administration will enable enhancement of overall information administration in higher education institutions in the realm of global competitive environment (Unachukwu \& Nwankwo, 2012).
On the criteria of an excellent ICT facility, taking into consideration Kling's opinion on an ideal ICT infrastructure from his study, the Philippines' Department of Information and Communication Technology's (DICT) ICT resources survey in universities in the country, the uses and benefits of ICT, and the core study of this research, the criteria of an ICT facility for school management should, therefore, be based on accessibility which refers to availability and convenience of ICT hardware and software and on user-ability of the people using the resources. Hence, an ICT facility input for school management must be comprise of the following criteria:

- Equipment such as computer, printer, scanner, photocopy machine, telephone, fax machine, external hard drive, and generator set, etc. [ (Kling, 1999) \& (Information and Communication Technology Office, 2012)]

- Latest OS (Kling, 1999)

- SIS with administrative subsystems i.e. Student Administration, Personnel Administration, Financial Administration, Timetable Administration, General School Administration, Test Administration and Resource Administration and managerial subsystems i.e. Capacity Planning, Educational Planning, Financial Planning, and School Year Evaluation (Maki, 2008). 
- Office Automation System (Information and Communication Technology Office, 2012).

- Database (Information and Communication Technology Office, 2012)

- Intranet or a campus-wide connection of LANs supported by fibre-optic and Unshielded Twisted Pair (UTP) technology (Kling, 1999)

- Sufficient bandwidth

- Internet Access and Email (Kling, 1999)

- Security, Disaster Recovery and Back Up Plan including Security Policy/Guideline, Back-Up Power Unit, Encryption, Hardware Firewall, Software Firewall, Subscription to security service (anti-virus system, intrusion alert), Regular ICT security training of employees, Disaster Recovery Plan, Digital Signatures, Offsite back-up, Physically restricted access to critical ICT equipment, Secure Servers, and Storage of backup media in localities other than the operating environment (Information and Communication Technology Office, 2012)

- Data Archiving System (Information and Communication Technology Office, 2012)

- Special Solution Packages i.e. Geographic Information System, Automated Fingerprint Identification
System, Cloud computing, and CCTV System (Information and Communication Technology Office, 2012)

- Data Centre (Information and Communication Technology Office, 2012)

- Official Website

- Competent Human Resource with the right knowledge and skills required to operate ICT resources (British Educational Communication and Technology Agency (BECTA), 2004)

However, how must it be put into use also plays a big role in the effectiveness and efficiency of the utilization of ICT resources. Basically, the process of exploitation of ICT relies on the user-ability of the human resource of an entity (British Educational Communication and Technology Agency (BECTA), 2004). Policy and guidelines, therefore, must be established on the process of using of ICT tools. According to the (University of Sydney, 2014) and (University of Southern Queensland, 2014) in their policies on the procedures of using ICT resources, all users must be lawful, efficient, economical and ethical in their use of a university's ICT Resources. These policy and guidelines are established in order to prevent or lessen the occurrences of the following negative consequences of the employment of ICT as discussed by (Etter \& Merhout, 2007), (McGill \& Bax, 2007), and (Yusuf, 2005): (i) Plagiarism, (ii) Absenteeism, and (iii) Malpractice. 
All in all, it is evident that technological change such as ICT has a massive influence in all aspects of education particularly in school management in the contemporary society. Obviously, a need to further develop guidelines and policies to enhance the effectiveness and efficiency of the usage of ICT is a must.

\section{METHODS}

The study's research design is a descriptive research study which utilizes both qualitative and quantitative methods. Thus as a descriptive study, this research has a detailed descriptions of the specific situation of the access and use of ICT in school management in MSU MC with the aid of a cross-sectional survey, interviews, and a document review on related studies.

\subsection{Demographic Background of the Respondents}

For the teachers and staff respondents, most of them, around $40 \%$, belong to the age interval between 33 to 49 years old. By gender, most of them are males with $53.3 \%$ of the respondents. By office, most of them are from CSD with $60 \%$ of the respondents. While by designation, most of them are teachers with $93.3 \%$ of the respondents.

For the student respondents, most of them, around $36.5 \%$, belong to the age interval between 17 to 19 years old. By gender, most of them are males with $52.7 \%$ of the respondents. By year level, most of them are in 4 th year of college with $24.3 \%$ of the respondents.
MSU main campus is the target population. The total population under the study speaks of the students, teachers and staff in every colleges and administrative offices including the ITC and other offices in the university who are deemed knowledgeable about the given subject at hand. The students, teachers and staff including the administrators of the ICT resources in MSU MC who reside in the ITC provide the information on the level of accessibility and use of ICT in terms of school management such as in enrolment, billing and other activities.

This study applied a stratified sampling method where the population is divided into several sub-populations that are individually more homogeneous than the total population (Kothari, 2004). In case of this research, the population was divided into three strata: the students of MSU MC, the teachers and staff of MSU MC and the administrators of the MSU MC - ITC. A purposeful sampling strategy was also applied in this study where only the population that were supposed wellinformed were selected (Amin, 2005). These two stratagems were taken as the sampling strategies to come up with a small size sample which will be an accurate representative of the study population. In the case of this research, the students and the teachers and staffs in MSU-CIT which is the Centre of ICT in the university were selected as the stratified and purposeful sample population.

For data gathering, both qualitative and 
quantitative research approaches in gathering, evaluating and handling data were utilized in this study. The primary data of this study were generated directly from the field and collected through interviews and self-administered questionnaires. While the secondary data were collected with the method of analysis of documents which includes official records, reports, as well as published data used in the review of literature.

An interview was set up for the administrators of the ITC about the issues to be explored in this study. The administrators of the ITC were specifically chosen for the interview since they are the most knowledgeable about the ICT infrastructures of MSU MC. The goal of it is to obtain accurate and in-depth information about the given topic. On the other hand, the survey which was conducted through questionnaires were designed such that each question relates to the given research question and the topic. It was made sure that the questions elicit data regarding the level of access and use of ICT in school management in MSU MC. It is semistructured where both close-ended and open-ended questions were used.

To establish the validity and reliability of this study, the validity and reliability of the instruments used to gather the primary data were checked through the guidance of the researcher's Thesis advisers. As for the secondary data, its validity and reliability was checked through identifying the authenticity of its source which can be done through paying attention to the definitions used, measurement error, source bias, and the time span of the secondary data (Green, Tull, \& Albaum, 1993).

After getting the consent to gather the data from the authorized officials (Thesis Proposal panel, Thesis advisers), the questionnaires were embedded in Qualtrics, a software that enables users to do many kinds of online data collection (Scott, 2012). Then, the links to the said questionnaires and interview questions in Qualtrics were posted in the official Facebook page of MSU MC - CIT where students and teachers are deemed to be knowledgeable about the MSU MC's ICT resources. PDF version of the questionnaires and the interview questions were also made available for download (in case the respondents are not comfortable with Qualtrics or what have you) which they then can send their responses to the researcher's Facebook inbox or to the researcher's email. Additionally, the links and PDFs of the questionnaires and the interview questions were also sent on emails of the respondents to ensure that more responses are gathered. And to even more make certain that there are respondents for this research study, a research assistant was also employed to conduct the survey and the interview directly from the field. Finally, a week was provided to the respondents to complete the questionnaires or the interview questions in the case of the administrators. The 
qualitative data from the interviews were analysed through a logical analysis. While the quantitative data from the questionnaires such as those from the close-ended questions were computed into statistical counts. Then, the quantitative data from the open-ended questions were analysed through the magnitude of the responses. And the information from the documentary sources and interviews helped bring out concrete evidence in the data analysed. Finally, to establish the relationship between the independent and dependent variables, statistical technique such as the chi-square test was put to use to test how the other variable affect the other variable. While the t-test was applied to determine whether there's a difference of opinions between the groups of respondents.

\section{RESULTS AND DISCUSSION}

\subsection{The Current State of the ICT Resources} Used for School Management in MSU MC in view of its Access and Use

On the level of accessibility of ICT resources in terms of its availability or the physical existence of the various ICT facilities in MSU $M C$, the respondents say that over-all they are Fairly Available on the average of 2.17. Similarly, on the level of accessibility of the ICT resources in terms of its convenience of access in MSU MC, the respondents claim that over-all they are Fairly Convenient to access on the average of 2.04. So, as a whole, the level of accessibility of the ICT resources in MSU MC is fairly available and fairly convenient to access. These results mean that the accessibility of ICT resources in MSU MC is not so much deficient but still requires necessary improvements in most aspects for the university to achieve its goal to become a fully technology-driven institution.

On the level of use pertaining to the userability of the human resource of MSU MC on ICT tools, the over-all opinion of the respondents reflects that it is good on the average of 3.61. These findings mean that the user-ability of the human resource of MSU MC particularly the teachers and administrative staff is decent enough.

On the level of impact of ICT on school management in MSU MC, the respondents say that on the average, ICT is Fairly Effective on school management with 2.14. These results signify that the application of ICT tools in the school management aspects of the university has been fairly effective which corresponds to the administrators' opinions that suggests ICT has made school management activities in MSU MC become faster, easier, efficient, and more reliable for both the students and the faculty and staff. However, room for improvements in the ICT facilities of the university is still a must.

\subsection{The Deficiencies of the ICT Resources} Used for School Management in MSU MC in view of its Access and Use

On the accessibility in terms of availability and convenience of access of ICT resources for school management in MSU $M C$, the open-ended questions from the 
questionnaires and from the interview of the administrators of the ITC, it is revealed that the following are the problems met in the access of ICT tools in the university:

- Slow to no internet connection

- Lack of maintenance on the existing resources

- $\quad$ Lack of computers

- Unstable electricity

- Lack of competent teachers

- Lack of updates on the new trends in ICT

This result proves that even though the respondents claim that the ICT facilities in MSU MC are fairly available and fairly convenient to access, the access of ICT resources in the university undoubtedly still needs enhancement since these problems on the access of ICT tools are important aspects of an ICT facility.

Whereas on the deficiencies on the use of ICT resources, the open-ended questions from the questionnaires and from the interview of the administrators of the ITC discloses the following as the hindrances of the use of ICT in MSU MC:

- Regular brown-outs

- Lack of Digital Literacy among teachers and administrative staff

- Lack of exposure to ICT tools of the teachers and administrative staff

- Lack of proper ICT training for the teachers and administrative staff

- $\quad$ Lack of computers

- Lack of maintenance and update on the latest ICT trends
- Slow internet connection

Similarly, this result proves that even though the respondents claim that the ICT userability of the human resource of MSU MC is good, these obstacles in the use of ICT tools in school management in the university reflects the need of development in the ICT use of MSU MC.

While talking about the negative consequences of ICT such as Abuse of ICT Resources, Malpractice, Plagiarism, and Defamation in the university, the result of this study tells that only Plagiarism is seen as the most prevalent in the university. This could be due to the reason that since the ICT facility in MSU MC is not yet highly advanced, such misdemeanors are not feasible with the university's current ICT resources.

\subsection{The Possible Strategic Area of} Opportunities for MSU MC Particularly in School Management after Setting-up the Essential Improvements in the Access and Use of its ICT Resources

According to the interview with administrators of the ITC, the improvements they want to see in the ICT facilities in the university are the following:

- Increase of bandwidth to internet

- Installation of Fibre Optics in the university's intranet

- Wi-Fi in every colleges and administrative offices

- $\quad$ More computers

- Additional Database for back-up 
- Hiring/Retaining of ICT competent human resource

According to the administrators, the increase of bandwidth of internet would not only speed up the internet connection of the university but also help in supporting systems that are available but can't be put into operation because of the absence of the required bandwidth. Then the installation of Fibre Optics in the intranet of the university would eradicate the problem of the university about sloppy enrolment since the connectivity will be strengthened compared to the use of UTP (Untwisted Pair) wire. Whereas, providing Wi-Fi for every college would motivate students as well as teachers to the use of ICT tools. It would also increase their exposure to the technology thus improving their knowledge and skills of ICT. While with more computers, easy access to information would be obtainable for both students and faculties of the university.

Furthermore, since MSU MC often experience brown-outs, the additional database for back-up would prevent losing data already in the system whenever there's a power outage. This would basically improve the operation of the university's SIS. But, of course, without the right people to manage these ICT facilities, the full capacity of this technology would not be realized. The MSU-ITC is composed only of 18 staff and some of these staff even takes turn as Instructors in the Computer Studies Department, so managing the over-all ICT facilities of the university is demanding with only few workers. Additional human resource with competent knowledge and skill in ICT would generally enhance the over-all function of the MSU - ITC.

\subsection{Correlation of the Variables}

The correlation of the variables is separately tested between the student and the teacher and staff respondents.

For the teacher and staff respondents, the following results were obtained on the correlation of the accessibility of ICT resources and effective school management:

$\mathrm{H}_{0}$ : There is no significant relationship between the Accessibility (in terms of availability and convenience) of ICT resources and the effectiveness of school management in MSU MC.

TABle 1. CORRELATION BETWEen ICT ACCESSIBILITY AND SCHOOL MANAGEMENT BASED ON TEACHER AND StAFF RESPONDENTS' OPINION

\begin{tabular}{lllll}
\hline & Chi-square & $\begin{array}{l}\text { Significance } \\
\text { Value }\end{array}$ & Remarks & Decision \\
\hline $\begin{array}{l}\text { Availability of ICT VS } \\
\text { Effective School }\end{array}$ & 0.355 & 0.551 & Not Significant & Accept Ho \\
$\begin{array}{l}\text { Management } \\
\text { Convenience of ICT VS }\end{array}$ & 0.355 & 0.551 & Not Significant & Accept Ho \\
$\begin{array}{l}\text { Effective School } \\
\text { Management }\end{array}$ & & & & \\
& & & &
\end{tabular}


On the correlation of the ICT user-ability of the human resource against effective school management, the teacher and staff respondents' result is as follows:
$\mathrm{H}_{0}$ : There is no significant relationship between ICT user-ability of the human resource and effective school management in MSU MC.

TABLE 2. CoRRELATION BETWEen ICT USER-ABILITY AND SCHOOL MANAGEMENT BASED ON TEACHER AND StAFF RESPONDENTS' OPINION

\begin{tabular}{lllll}
\hline & Chi-square & $\begin{array}{l}\text { Significance } \\
\text { Value }\end{array}$ & Remarks & Decision \\
\hline User-ability of ICT VS & 0.355 & 0.551 & Not Significant & Accept Ho \\
Effective School & & & & \\
Management & & & &
\end{tabular}

and effective school management in MSU MC.

For the student respondents, the following results were obtained on the correlation of the accessibility of ICT resources and effective school management:

$\mathrm{H}_{0}$ : There is no significant relationship between the Convenience of access of ICT resources and $\mathbf{H}_{1}$ : There is a significant relationship effective school management in between Availability of ICT resources MSU MC.

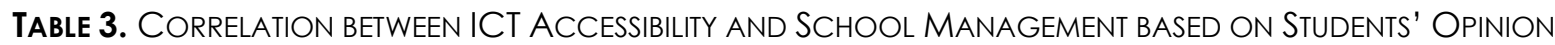

\begin{tabular}{lllll}
\hline & Chi-square & $\begin{array}{l}\text { Significance } \\
\text { Value }\end{array}$ & Remarks & Decision \\
\hline $\begin{array}{l}\text { Availability of ICT VS } \\
\text { Effective School }\end{array}$ & 14.694 & 0.005 & Significant & Reject Ho \\
$\begin{array}{l}\text { Management } \\
\text { Convenience of ICT VS }\end{array}$ & 6.312 & 0.117 & Not Significant & Accept Ho \\
Effective School & & & & \\
Management & & & &
\end{tabular}

On the correlation of the ICT user-ability of the human resource against effective school management, the student respondents' result is as follows:
$\mathbf{H}_{1}$ : There is a significant relationship between the user-ability and school management in MSU MC.

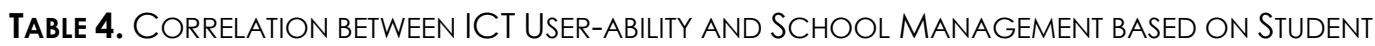
RESPONDENTS' OPINION

\begin{tabular}{lllll}
\hline & Chi-square & $\begin{array}{l}\text { Significance } \\
\text { Value }\end{array}$ & Remarks & Decision \\
\hline User-ability of ICT VS & 15.323 & 0.000 & Significant & Reject $\mathrm{H}_{0}$ \\
Effective School & & & & \\
Management & & & &
\end{tabular}





\subsection{Comparative Analysis of the}

\section{Respondents Opinions}

A t-test was employed to compare whether there is a significant difference or not between the student and the teacher and staff respondents' opinions on the access and use of ICT resources in school management in MSU MC.

On the level of access in terms of availability and convenience of ICT resources, the following results come up:
$\mathbf{H}_{1}$ : There is a significant difference between the student and the teacher and staff respondents' opinions on the availability of ICT resources for school management in MSU MC.

$\mathbf{H}_{1}$ : There is a significant difference between the student and the teacher and staff respondents' opinions on the convenience of ICT resources for school management in MSU MC.

TABle 5. Comparative ANALYSIS Of THE StUdentS AND tHE TEACHER AND StAfF RESPONDENTS ON THE LEVEL OF ACCESSIBILITY IN TERMS OF AVAILABILITY AND CONVENIENCE OF ICT RESOURCES IN SCHOOL MANAGEMENT IN MSU MC

\begin{tabular}{lllll}
\hline & T Test & $\begin{array}{l}\text { Significance } \\
\text { Value }\end{array}$ & Remarks & Decision \\
\hline Availability of ICT & 2.03 & 0.05 & Significant & Reject $\mathrm{H}_{0}$ \\
Convenience of ICT & 2.67 & 0.01 & Significant & Reject Ho
\end{tabular}

On the level of ICT user-ability of the human resource on ICT resources, the following results came up:
$\mathbf{H}_{1}$ : There is a significant difference between the student and the teacher and staff respondents' opinions on the user-ability of the human resource on ICT resources for school management in MSU MC.

Table 6. Comparative Analysis of the Students and the Teacher and Staff Respondents On the LeVel OF USER-ABILITY OF THE HUMAN RESOURCE ON ICT RESOURCES FOR SCHOOL MANAGEMENT IN MSU MC

\begin{tabular}{lllll}
\hline & T Test & $\begin{array}{l}\text { Significance } \\
\text { Value }\end{array}$ & Remarks & Decision \\
\hline User-ability of ICT & 17.29 & 0.000 & Significant & Reject Ho
\end{tabular}

On the level of impact of ICT on school management, the comparative analysis result is as follows:
$\mathbf{H}_{1}$ : There is a significant difference between the student and the teacher and staff respondents' opinions on the impact of ICT resources in school management in MSU MC. 


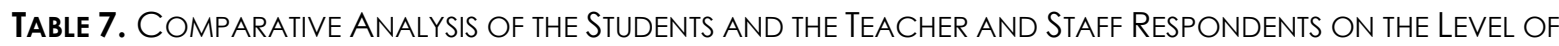
IMPACT OF THE HUMAN RESOURCE ON ICT RESOURCES FOR SCHOOL MANAGEMENT IN MSU MC

\begin{tabular}{lllll}
\hline & T Test & $\begin{array}{l}\text { Significance } \\
\text { Value }\end{array}$ & Remarks & Decision \\
\hline Effectiveness of ICT in & 2.12 & 0.04 & Significant & Reject Ho \\
School management & & & &
\end{tabular}

\section{CONCLUSION AND}

\section{RECOMMENDATION}

\subsection{Conclusion}

The following are the draw conclusions from this research:

1. The ICT infrastructure for school management utilized in MSU MC is fairly available and convenient to access. This finding is not so much wanting however the areas where MSU MC is lacking are pretty much important aspects of an excellent ICT facility such as internet connectivity, competent human resource, and computers. On the positive note though, at least MSU MC already has something to build on even if it is not completely adequately available and conveniently accessible.

2. The ICT user-ability of the human resource of MSU MC in terms of those ICT tools used for school management is considered as fair to good. This finding is decent enough. However, complaints on the knowledge and skills of the teachers and staff with regards to ICT tools are still there. ICT user-ability of the human resource still remains as the biggest challenge affecting the implementation of ICT in the university.
But similarly to ICT accessibility, MSU MC at least, already has something to build on with its current faculty and staff.

3. The impact of the current ICT facilities in MSU MC in the school management activities of the university has been fairly effective. And if the deficiencies in them-lack of internet bandwidth, competent human resource, and computers-are addressed, strategic opportunities such as: Faster internet, enough internet bandwidth to support systems, faster data processing, more exposure of the stakeholders to ICT and Better workforce, will be obtainable for the university. On the other hand, of the negative effects of $I C T$, only plagiarism is seen as rampant.

4. Even though, majority of the respondents' opinions expressed no direct relationship between ICT Accessibility (Availability and Convenience) and school management, the benefits that ICT brings in to school management procedures is visible and proven through various researches.

5. Even though, the student and the teacher and staff respondents didn't have the same opinion on the 
significant relationship of ICT userability and school management, many researchers still claim that the effectiveness of the implementation of ICT in education in general still lies at the people's attitude and skills in utilizing the said technology. In the first place, school management is done by the people and not by this technology.

6. The comparative analysis of the student and the teacher and staff respondents' opinions reveal that the there is a significant difference between the opinions of these two groups of respondents on the accessibility (availability and convenience) of ICT resources, the ICT user-ability of the human resource and the effectiveness of ICT in school management in MSU MC. However, it can be noted that these disparities of their opinions are not wide due to the little difference of value between the resulted $p$-values and the 0.05 level of significance.

7. Even though the level of ICT user-ability of the human resource in MSU MC is labelled as good, the level of accessibility and effectiveness of the ICT facilities in the university is still deemed as only fairly accessible and fairly effective due to the deficiencies met in the ICT facility for school management in the university. That is to say that the deficiencies of the ICT facilities in the university overpower the positive side of MSU MC's ICT tools.

8. The results also show that effective school management is not parallel with the accessibility and user-ability of ICT tools in school management.

\subsection{Recommendations}

Based on the findings of this research, the following are the recommendations that could be considered to improve the application of ICT in the school management aspect of MSU MC:

1. The accessibility of ICT facilities in MSU MC should be improved through:

(i) upgrading the internet connection bandwidth of the university to allow easy access on the world wide web and support other valuable systems that couldn't be run due to lack of internet bandwidth;

(ii) opening the stakeholders in the world of ICT by liberalizing internet connection thru establishment of Wi-Fi hotspots in every colleges and administrative offices;

(iii) mounting Fibre Optics cable to replace the UTP wires utilized in the university in order to speed up the campus-wide information processing through MSU MC's intranet:

(iv) installing new computers with higher processing power in the university; and 
(v) using old computer as computer kiosks in conveniently accessible places to allow students and teachers and staff alike who don't own personal computers an easy access to the ICT facility of the university.

2. The user-ability of the human resource in ICT in the university should be developed through:

(i) holding a mandatory universitywide seminar on the usage of the ICT facilities in the university and on the basic and important ICT knowledge and skills that must be learned; and

(ii) hiring and retaining ICT competent human work force

(iii) introducing more topics on ICT on the curriculum of the university

3. An income generating plan should be made to support the excessive use of the back-up power supply of the university and the maintenance and update that the ICT resources in MSU $M C$ requires.

\section{ACKNOWLEDGEMENT}

The Government of the Republic of Indonesia for the scholarship. The Universtas Ahmad Dahlan (UAD) especially to the Program PASCASARJANA and the Education Management department

\section{REFERENCES}

Bushweller, K. (2000). The smarter office: how school districts are automating administrative tasks. Retrieved from The Electronic School: http://www.electronicschool.com/2 000/03/0300f2.html

Crawford, M. (2001). King John's Christmas: developing leadership communities on-line. Seattle, WA.

Evans, M. (2002). Open windows: becoming an e-learning school. Retrieved from National College for School Leadership: http://www.ncsl.org.uk/mediastore/ image2/evans-open-windows.doc

IGSCE ICT. (2014). School Management Systems. Retrieved from IGSCE ICT: http://www.igsceict.info

Megan. (n.d.). The Impact of ICTs on the Design and Delivery of Public Services. Retrieved from http://www.3s4.org.uk/news/theimpact-of-ict-on-the-design-anddelivery-of-public-services

Microsoft Encarta 2009 [DVD]. (2009). Accessible. Redmont, Washington, USA.

National Council for Curriculum and Assessment, UK. (2004). Curriculum 
Assessment \& ICT in the Irish context:

A discussion paper.

Network for IT-Research and

Competence In Education. (2004).

PILOT: ICT and School

Development. Retrieved from

Network for IT-Research and

Competence In Education (ITU):

http://www.itu.no

North, R., Strain, D., \& Abbott, L. (2000). Training teachers in computerbased management information systems. Journal of Computer Assisted Learning, 27-40.

OCC. (2010). MIS. Retrieved from OCC: http://www.occ.gov/publications/p ublications-by-type/comptrollershandbook/mis.pdf

Perry, D. (2003). Handheld computers (PDAs) in schools. Retrieved from British Educational Communication and Technology Agency (BECTA): http://www.becta.org.uk/research/ reports/docs/handhelds.pdf

Price Water House Coopers (PWC). (2001). Teacher workload study: final report. Retrieved from http://www.teachernet.gov.uk/_do c/3165/Final\%20report\%205\%20Dec ember\%20CK3dec2.doc
Sopchokchai, O. (2004). Uses of ICT in improving Government workflow and process reform. Retrieved from http://www.adbi.org/files/2004.10.05.c mats.ict.government.workflow.pdf.

Telem, M. (2001). Computerisation of school administration: impact on the principal's role: a case study. Computers and Education, 345-362.

The ICT Lounge. (2014). ICT in School Management. Retrieved from The ICT Lounge: http://www.ictlounge.com

Yee, D. (2000). Images of school principals' information and communications technology leadership. Journal of Information Technology for Teacher Education, 287382. 